\title{
A sustainable approach for livelihood improvement and integrated natural resource management in Central Himalaya, India
}

\author{
D. S. Chauhan ${ }^{1}$, D. S. Bisht ${ }^{2}$, Mukesh Deorai ${ }^{1}$, D. S. Rawat ${ }^{1}$ and \\ R. C. Sundriyal ${ }^{2}$ * \\ ${ }^{1}$ G.B. Pant National Institute of Himalayan Environment and Sustainable Development, Kosi-Katarmal, Almora 263 443, India \\ ${ }^{2}$ Department of Forestry and Natural Resources, H.N.B. Garhwal University, Srinagar (Garhwal) 249 161, India
}

\begin{abstract}
The present study highlights augmentation of livelihood and natural resource management in the Central Himalayan region by promoting community-specific strategies, adoption of appropriate technologies, diversification of on-farm and off-farm activities, cash-crop production, and supporting ecological restoration and natural resource management. A cluster of eight villages having 470 households was targeted and actions related to community mobilization, micro-planning, technology demonstration and dissemination, the establishment of market linkages, capacity-building and formation of self-help groups were undertaken. Farmers adopted nine technology packages that diversified agriculture in waste/abandoned lands. Management of forests and use of Chir-pine needles for making by-products not only provided an additional source of livelihood but also helped in controlling forest fire. Facilitating linkages with line departments helped to acquire benefits of government schemes. It is recommended that region-specific approach, collective action, targeting weaker sections and women, efficient natural resource management, livelihood enhancement, and capacity-building and community empowerment will lead to a sustainable approach for community development in the Himalayan region.
\end{abstract}

Keywords: Community empowerment, livelihood improvement, natural resource management, technology packages, sustainability.

\section{Introduction}

THE Himalayan region harbours rich bioresources that fulfil diverse needs of local communities, and people of the region possess enormous wisdom to manage various natural resources. The livelihood of people in the region is primarily dependent on natural resources comprising agriculture, livestock, horticulture, forest, pastures, etc. ${ }^{1}$. Agriculture is the main economic activity, which is largely rainfed and performed using traditional practices. The

*For correspondence. (e-mail: sundriyalrc@yahoo.com) land holding sizes are much smaller (74\% of the holdings are less than $1 \mathrm{ha}$ ) with higher per unit input cost than output in the hills than the plain areas ${ }^{2}$. The communities depend on forests for diverse goods and services ${ }^{3}$. Majority of the regions lack proper marketing facilities; therefore, the communities sell their products at a minimal price. In recent years the soil has been poor and subjected to erosion at many places, which limits agriculture production ${ }^{4}$. There has been an increasing risk of crop failure and uncertainty of optimum production, which is often linked to climate change ${ }^{5}$. The people of the region are poor, marginalized and disadvantaged, and to earn a better livelihood they migrate to plain areas in search of employment ${ }^{6}$. Forest degradation, deterioration of natural resources, abandonment of agriculture land due to low productivity and increasing poverty are major threats to the livelihoods of people living in the region ${ }^{4}$.

The state of Uttarakhand in India comprises a total land area of 56.72 lakh ha, $86 \%$ of which is mountainous. A major chunk is under forests and wastelands. Over $70 \%$ of the populations depend on agriculture and natural resources, particularly on forests, for their livelihood ${ }^{7}$. Low agricultural productivity, loss of biodiversity and degradation of forest cover are often interlinked problems in the hill region that threaten the sustainable livelihood of communities $^{8}$. There is an urgent need to find possible solutions to upgrade the livelihood and economic status of communities, and protect the environment and quality of life in the region ${ }^{2}$. Fortunately, it is possible to make the farming system more profitable by increasing productivity through crop diversification, switching over to cash crops, managing barren/wastelands, promoting organic production, strengthening post-harvest management, development of market linkages, adoption of technologies, use of appropriate farm machinery, promoting fodder and fruit species, and water harvesting structure ${ }^{9,10}$. The distinct agro-climatic conditions of the state are favourable for the development of horticulture, mainly for production of fruits, vegetables and floriculture. Use of forest produce and its sustainable management also has ample scope for livelihood improvement ${ }^{11}$. Chir-pine is a major forest type that covers about $16 \%$ of the forest area in 
Uttarakhand. In low hill areas, most of the villages are situated in the vicinity of chir-pine forests that are susceptible to forest fires. In recent years there has been a significant increase in accidental forest fires causing huge environmental problems. This highlights the need to utilize dry chir-pine needles for productive purposes that will not only reduce forest fires, but also generate income avenues for communities, particularly for the poor and marginalized people. Considering this, a programme for livelihood improvement and integrated natural resource management was undertaken in the Central Himalaya with an aim to extend technical know-how and packages for demonstrating on- and off-farm activities for improving livelihood and environmental health; empowering and capacity-building of the local communities, particularly women and weaker sections by enhancing knowledge, skill, strengthening local institutions and governance mechanisms, and promoting integrated and adaptive natural resource management using innovative participatory approaches. The project has been supported under the National Mission on Himalayan Studies (NMHS) and being implemented for the past three years. The broad approach and major findings are discussed in this article.

\section{Study area}

The project was implemented in a remote village cluster situated between $9^{\circ} 40^{\prime} 750^{\prime \prime} \mathrm{N}$ and $79^{\circ} 36^{\prime} 859^{\prime \prime} \mathrm{E}$ in Hawalbagh development block, Almora district, Uttarakhand (Figure 1). Selection of the area was done after detailed survey and interactive meetings with village communities and district administration. A cluster of eight villages (viz. Darimkhola, Sakar, Gwalakot, Jyula, Sakniyakot, Tiloura, Bhelgarh and Pithrar) was selected that comprised broad characteristics of Lesser Himalayan region with mountainous topography, dense population, dominance of rainfed and subsistence agriculture, abandonment of cultivated lands, high dependence on forest, prevalence of chir-pine, significant out-migration in view of limited economic opportunities, and ecosystem degradation in terms of decline in the status of land, forest, water and pasture. According to the 2011 census these villages comprised 470 households (population 1977, male $46.1 \%$, female $53.9 \%$ ). About $25.9 \%$ of the total population constitutes scheduled caste (SC). As such the area exhibits a literacy rate of $72.78 \%$ (male $84.63 \%$, female $62.66 \%$ ). Collectively these villages comprise a total of 760.43 ha $(30.61 \%)$ land area under agriculture that is largely rainfed.

\section{Project implementation approach and methods}

The project implementation approach comprised of (i) livelihood upgradation by increasing income, improve- ment in agricultural productivity and availability of biomass; (ii) improving environmental and ecological restoration; (iii) strengthening village institutions and sustainable governance, and (iv) improving access to Government-run schemes, programmes and services. A team was hired to undertake all envisaged activities. The project planning and implementation was carried out in a participatory manner. Before the start of the interventions, a baseline assessment of community socio-economic status and status of available resources in the target villages was undertaken. Regular community meetings were organized to identify problems related to livelihoods and natural resources that were categorized according to different sectors. Selection of beneficiaries, identification of technologies and demonstration of technologies was carefully planned with community consultation after a need assessment survey at the start of the project. Necessary technical and financial back-up was extended to the village community. Trainings and workshops were organized to develop community skills and knowledge for sustainable natural resource management at the Rural Technology Complex (RTC) of the G.B. Pant Institute. Initially farmers were given primary exposure to diverse technologies so as to opt for a model of their choice, followed by intensive capacity-building in the same technology. The main beneficiaries were women and SC families from the low-income group. The partner organizations comprised village-level institutions (Gram Sabha, Gram Panchayat), an NGO (Mahila Haat) and self-help groups (SHGs) that were working in the area. Besides, a liaison was also developed with the district administration and line departments (horticulture, livestock, agriculture, rural departments). Interactive sessions were

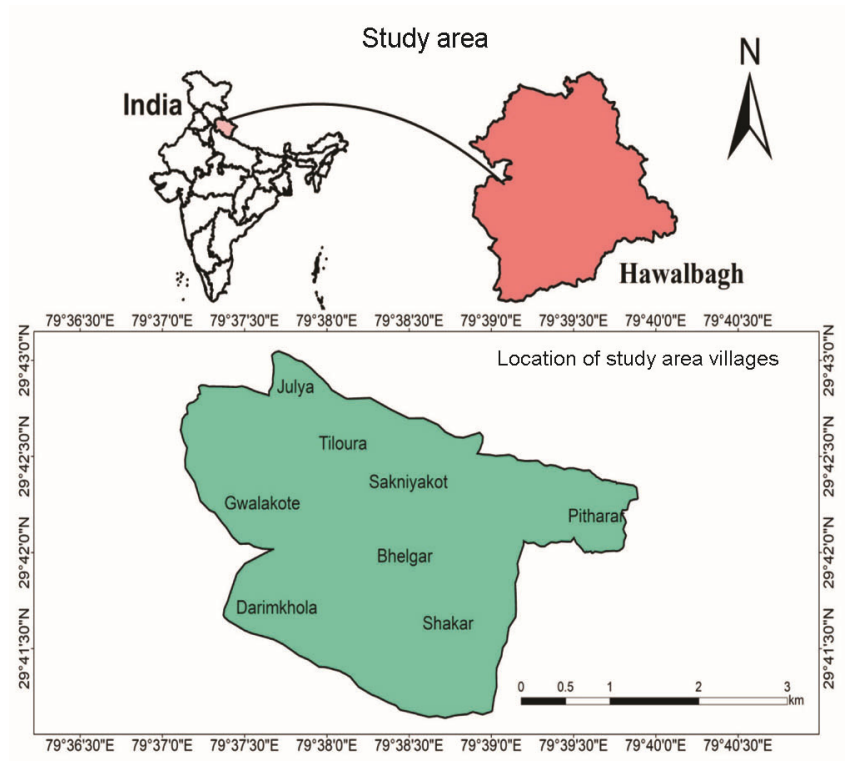

Figure 1. Location map of the study area exhibiting target villages in Hawalbagh development block, Almora district, Uttarakhand, India. 
Table 1. General characteristics of the study villages in Hawalbagh development block, Almora district, Uttarakhand, India

\begin{tabular}{|c|c|c|c|c|c|c|c|c|c|}
\hline \multirow[b]{2}{*}{ Parameters } & \multicolumn{9}{|c|}{ Village } \\
\hline & Darimkhola & Gwalakot & Jyula & Tiloura & Sakar & Sakania kot & Bhelgar & Pitharar & Total \\
\hline Total geographical area (ha) & 75.78 & 166.37 & 49.4 & 62.57 & 213.1 & 140.13 & 15.09 & 37.99 & 760.4 \\
\hline Total no. of households & 83 & 113 & 73 & 49 & 65 & 55 & 24 & 8 & 470 \\
\hline Total population & 338 & 438 & 313 & 202 & 295 & 242 & 118 & 31 & 1977 \\
\hline Male & 165 & 197 & 138 & 86 & 141 & 115 & 52 & 17 & 911 \\
\hline Female & 173 & 241 & 175 & 116 & 154 & 127 & 66 & 14 & 1066 \\
\hline $\mathrm{SC}$ & 110 & 89 & 191 & 0 & 76 & 47 & 0 & 0 & 513 \\
\hline Livestock & 190 & 232 & 154 & 88 & 142 & 122 & 190 & 28 & 1146 \\
\hline Per capita cultivated land (ha) & 0.04 & 0.12 & 0.04 & 0.11 & 0.14 & 0.27 & 0.06 & 0.10 & 0.11 \\
\hline
\end{tabular}

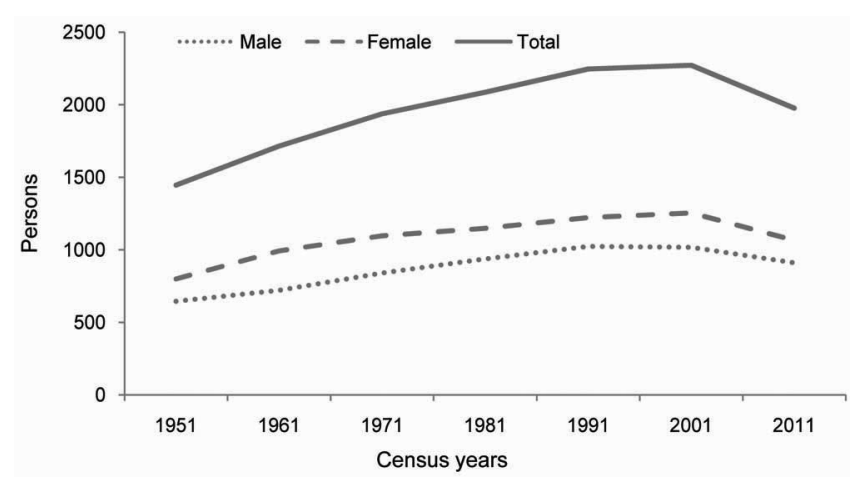

Figure 2. Trend of population growth in the study area.

organized between farmers, the NGO and representatives of the line departments to finalize an action plan.

\section{Results and discussion}

\section{Village profile}

Table 1 presents the details of the target villages and major characteristics. The total population of villages was 1977 persons (470 households). The population registered a continuous growth during 1951 to 2001, and thereafter a decline in 2011 (Figure 2). The trend of population growth was similar to Almora district, which had also registered a negative growth during 2001-2011 due to out-migration. As many as 1119 persons (247 families) have permanently migrated from these villages since 1991 and settled down in towns and cities. The area has high literacy $(72.78 \%)$, higher for males $(84.63 \%)$ than females $(62.66 \%)$. The per capita land-holding size was small $(0.04-0.27$ ha), and nearly $89.6 \%$ of the farmers had marginal land holding $(<1$ ha) (Figure 3 ).

A total of six major land-use categories were identified for the studied villages, i.e. cultivated land (30.61\%), cultivable wasteland $(15.60 \%)$, fallow land $(9.45 \%)$, barren land $(26.05 \%)$, forest land $(8.44 \%)$, and pastures/grazing land $(5.18 \%)$ (Table 2). Majority of the land was rainfed $(87.1 \%)$, while irrigated land was much less $(12.9 \%)$. The cultivable wasteland comprised of abandoned agricultural fields of the community that could be put to productive use.

The broad socio-economic status of the villages comprised of $87.44 \%$ of the total working population engaged in agriculture and allied activities (2011 Census). However, a primary survey in 2017 revealed that the number of people engaged in agriculture and allied activities has declined drastically. At present, the marginal and small land-holders meet $70-80 \%$ and $68-80 \%$ of income from the secondary (construction and mining) and tertiary (trade, transport and other services) sectors, respectively. However, for semi-medium land holders $30-46 \%$ of the income is still met from the primary sector (agriculture and allied activities).

\section{Project interventions, community mobilization and village development}

Table 3 provides details of broad project implementation approach and strategy of village development, major interventions and demonstration, number of beneficiaries, and impact. At the start of the project separate community meetings were organized in all target villages to decipher the project aims, approach and possible benefits. A transparent community mobilization and beneficiary selection process was taken up involving all community members. The community needs were mapped and prioritized. The potential community leaders and progressive farmers were identified. All villagers were given exposure and training at RTC on a collection of 40 technologies for dissemination. The community was allowed to opt for any of the feasible technologies that they considered best for them. Subsequently, a total of ten training sessions were organized for marginal and resource-poor farmers on different livelihood enhancement technologies benefitting 291 persons $(65.30 \%$ of the beneficiaries were women and $31.27 \%$ belonged to SC). Regular community meetings/interactions were organized to coordinate and implement project-related activities (Table 3 ).

Keeping in view the land-use types and socioeconomic set up of the study area, various low-cost, ecofriendly technologies for sustainable utilization and 
SPECIAL SECTION:

Table 2. Major land-use patterns of the study villages

\begin{tabular}{|c|c|c|c|c|c|c|c|c|c|}
\hline Land-use type & Darimkhola & Gwalakot & Jyula & Sakar & Tiloura & Sakaniakot & Bhelgar & Pitharar & Total area (ha) \\
\hline Cultivated area & 16.73 & 54.03 & 15.18 & 43.16 & 23.88 & 66.49 & 7.66 & 5.64 & 232.77 \\
\hline Cultivable wasteland & 23.46 & 22.96 & 4.51 & 10.02 & 10.13 & 37.46 & 2.14 & 7.97 & 118.65 \\
\hline Pastures and other grazing land & 4.94 & 10.32 & 6.67 & 0 & 8.15 & 0 & 0 & 9.36 & 39.44 \\
\hline Barren land & 1.03 & 52.46 & 7.73 & 116.05 & 5.11 & 2.68 & 0.79 & 12.26 & 198.11 \\
\hline Fallow land & 15.21 & 11.94 & 1.66 & 35.46 & 3.83 & 0 & 1.02 & 2.76 & 71.92 \\
\hline Forest area & 12.31 & 4.2 & 8.7 & 0 & 5.95 & 30.21 & 2.87 & 0 & 64.24 \\
\hline
\end{tabular}

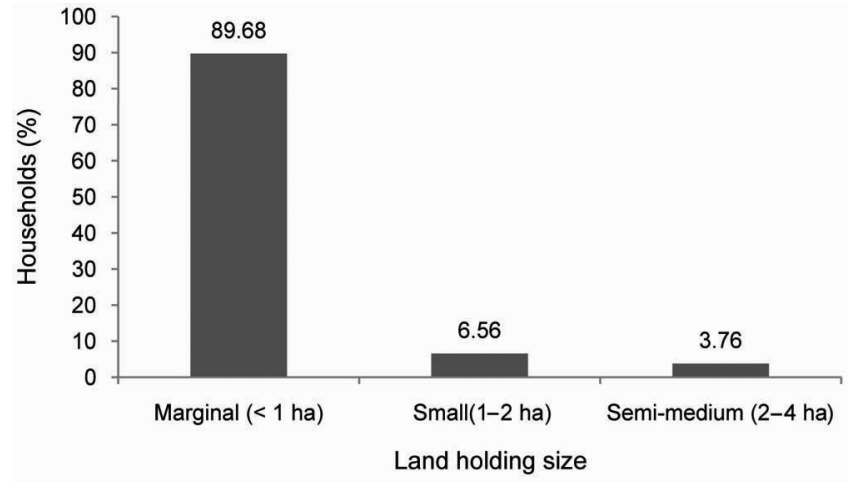

Figure 3. Land-holding size in the study area.

management of natural resources were identified and demonstrated in the target villages. The selected technologies comprised of protected cultivation, vermicompost, biocompost, cash-crop cultivation, vegetable cultivation, horticulture, integrated fish farming, poultry farming, organic farming, multipurpose tree plantation, making decorative items, bio-briquetting, and house waste (degradable)-based biogas system.

\section{Demonstration and dissemination of technologies}

To improve livelihoods and natural resource management and to increase land productivity, a number of technological models were demonstrated. A total of 21 farmers adopted protected cultivation of organic vegetables and compost-making (vermicomposting, biocomposting). One-third of the total polyhouses (size $10 \times 30 \mathrm{ft}$ ) were constructed using locally available bamboo that reduces cost. All beneficiaries were supported with UV-poly film for promoting protected cultivation that is ideally suited to small land-holdings. High-yielding seeds of tomato, capsicum, cucumber, cabbage and French beans were supplied. The vegetables were ready for sale within three months, at least one month earlier than growing the same vegetables in open condition. This attracted farmers as early supply of crops fetched high prices. All the beneficiaries were also motivated to use composts (vermicompost and biocompost) in their polyhouses and other farming lands. Vermicompost models were developed for the conversion of biological waste (cattle-feed waste, poultry-feed waste, vegetable waste, dry waste, etc.) into valuable organic manure using earthworm as a biological tool. Four vermi-compost models were established under the project, while 15 others were constructed with the help of line departments. The average income of the beneficiaries varied between Rs 7295 and Rs 12,620. Positioning of more poly houses can substantially increase farmers' income.

Other than vegetables cultivation of high-value cash crops, horticulture species, integrated fish farming and poultry farming was also promoted. Farmers were motivated to opt for collective farming of high-value cash crops on their abandoned and low-productive agriculture lands. A chunk of 2.5 ha abandoned land belonging to 21 families was earmarked for cultivation of ginger, that is not damaged by wild and domestic animals. A total of $10 \mathrm{q}$ of quality seeds (rhizome) of ginger was planted. The crop yield recorded was $83.18 \mathrm{q} / \mathrm{ha}$ and the farmers earned nearly Rs 5 lakhs by selling ginger. The land has now been completely rehabilitated and families are reconnected to their lands, which they had abandoned earlier. In order to increase the yield of low cultivated lands, farmers have adopted high-value cash crops (onion, garlic, potato and turmeric) in place of traditional crops (wheat, paddy and finger millet). A total of 305 farmers opted for high-value cash crops and the project helped them to undertake collective farming in 12.71 ha consolidated land. The production of cash crops was much higher than the traditional crops (Table 4). An economic analysis of traditional and cash crops revealed that cultivation of cash crops is more cost-effective (Table 5). Since the area has been doing organic farming since ages, the farmers were encouraged to maintain the same. Efforts were also made to promote contract farming; however, at present most farmers are reluctant to do so. Another important intervention was to produce quality vegetables in kitchen gardens. A total of 46 households initiated this and have started earning good returns. It was recorded that with limited technology adoption, the income of farmers can be increased by $16.6-39.5 \%$ (Table 6). It mostly helped marginal and small land holders, who otherwise moved to towns and cities in search of employment.

A change in the traditional calendar of crop cultivation was realized through the interventions in this study that helped the farmers to earn better income (Figure 4). 


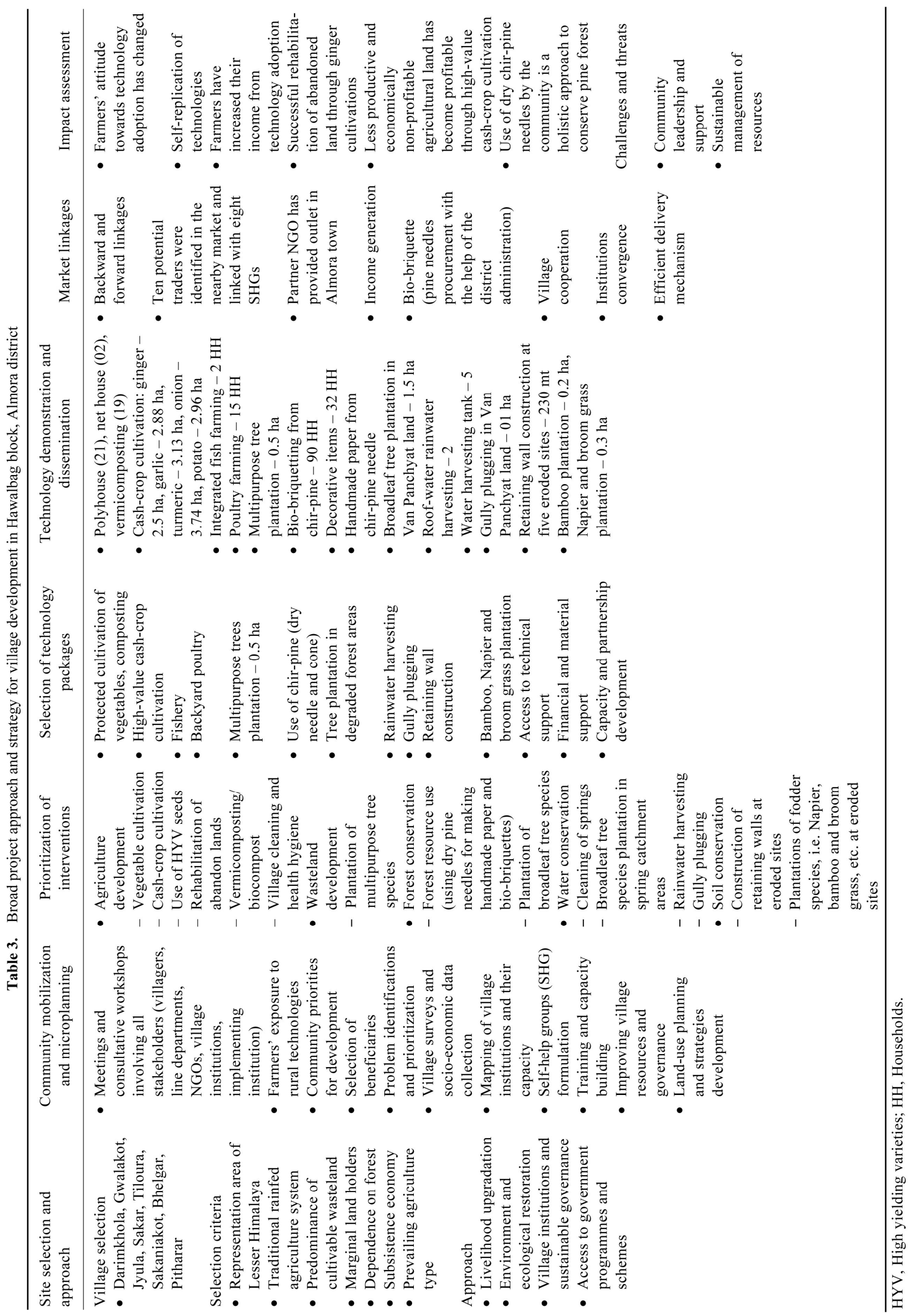


Table 4. Traditional crop versus cash-crop production ( $\mathrm{q} / \mathrm{ha})$ on rainfed lands

\begin{tabular}{|c|c|c|c|c|c|}
\hline Target villages & $\begin{array}{c}\text { Total cultivated land } \\
\text { available in the } \\
\text { villages (ha) }\end{array}$ & Crops & $\begin{array}{l}\text { Crop sown } \\
\text { area }\end{array}$ & $\begin{array}{c}\text { Total production } \\
\text { (q/ha) }\end{array}$ & $\begin{array}{l}\text { Total value as per current } \\
\text { market rate }(\mathrm{Rs} / \mathrm{q})\end{array}$ \\
\hline \multirow[t]{7}{*}{ Darimkhola and Gwalakot } & 70.76 & Paddy & 15.16 & 15.62 & $27,339.71$ \\
\hline & & Wheat & 13.24 & 17.86 & $32,589.48$ \\
\hline & & Finger millet & 21.832 & 10.75 & $31,133.36$ \\
\hline & & Onion ${ }^{\#}$ & 1.78 & 115.06 & $230,119.44$ \\
\hline & & Garlic $^{\#}$ & 1.34 & 37.89 & $227,311.79$ \\
\hline & & Potato $^{\#}$ & 0.26 & 81.39 & $162,780.00$ \\
\hline & & Turmeric $^{\#}$ & 1.54 & 53.24 & $159,720.19$ \\
\hline \multirow[t]{7}{*}{ Jyula and Tiloura } & 39.06 & Paddy & 8.56 & 15.35 & $26,859.23$ \\
\hline & & Wheat & 6.58 & 18.19 & $33,191.15$ \\
\hline & & Finger millet & 7.41 & 10.21 & $29,591.62$ \\
\hline & & Onion $^{\#}$ & 1.02 & 115.53 & $231,058.43$ \\
\hline & & Garlic $^{\#}$ & 0.96 & 35.80 & $214,812.50$ \\
\hline & & Potato $^{\#}$ & 1.14 & 92.24 & $184,474.91$ \\
\hline & & Turmeric $^{\#}$ & 0.78 & 43.40 & $130,200.00$ \\
\hline \multirow[t]{7}{*}{ Sakar and Pithrar } & 48.8 & Paddy & 12.79 & 15.68 & $27,431.63$ \\
\hline & & Wheat & 12.34 & 18.67 & $34,065.68$ \\
\hline & & Finger millet & 5.92 & 10.20 & $29,537.66$ \\
\hline & & Onion $^{\#}$ & 0.51 & 115.74 & $231,473.73$ \\
\hline & & Garlic $^{\#}$ & 0.24 & 43.76 & $262,572.50$ \\
\hline & & Potato $^{\#}$ & 0.98 & 135.66 & $271,325.31$ \\
\hline & & Turmeric $^{\#}$ & 0.4 & 55.64 & $166,920.00$ \\
\hline \multirow[t]{7}{*}{ Sakniyakot and Bhelgarh } & 74.15 & Paddy & 6.98 & 15.05 & $26,330.23$ \\
\hline & & Wheat & 5.8 & 18.51 & $33,787.67$ \\
\hline & & Finger millet & 8.418 & 10.72 & $31,069.28$ \\
\hline & & Onion $^{\#}$ & 3.735 & 115.13 & $230,265.60$ \\
\hline & & Garlic $^{\#}$ & 2.88 & 38.06 & $228,377.92$ \\
\hline & & Potato $^{\#}$ & 2.9552 & 136.67 & $273,349.69$ \\
\hline & & Turmeric $^{\#}$ & 3.125 & 49.91 & $149,721.60$ \\
\hline
\end{tabular}

${ }^{\#}$ Cash crops.

Table 5. Comparative account of cost : benefit analysis of traditional and cash crops in target villages (values in Rs/ha)

\begin{tabular}{lccc}
\hline Crops & Production cost & Total return & Net income \\
\hline Traditional crops & & & \\
$\quad$ Paddy & $71,925.5$ & $77,460.0$ & $5,534.5$ \\
Wheat & $58,870.5$ & $51,035.0$ & $-7,835.5$ \\
$\quad$ Finger millet & 49,169 & $44,599.5$ & $-4,569.5$ \\
Cash crops & & & \\
Onion & $115,553.5$ & $196,303.5$ & 80,750 \\
Garlic & $109,463.5$ & $215,846.5$ & 106,383 \\
Potato & $173,915.0$ & $240,820.0$ & 66,905 \\
Turmeric & $158,749.0$ & $222,311.5$ & $63,562.5$ \\
\hline
\end{tabular}

Traditionally in rainfed areas farmers practice a two-year crop cycle, i.e. dhansar and maduasar. In dhansar (kharif) paddy has been the main crop that is cultivated during rainy season followed by wheat (rabi). In 'maduasar' it is finger millet (Eleusine coracana) in the next kharif season followed by a fallow period during the next rabi season. With the help of the project, farmers have started cultivating cash crops such as ginger and turmeric along with paddy during the kharif season, and garlic, onion and potato along with wheat during the rabi season (Figure 4).

Two models of pond-based integrated fish farming have been demonstrated in the study area comprising fishery + poultry + vegetable + vermicompost units. The families were provided chick-birds, fingerlings and goodquality vegetable seeds to develop integrated fish-farming models. Each beneficiary farmer has earned nearly Rs 40,000 as additional income in a year from integrated fish farming. Besides, a total 15 households were given 1500 chick-birds to initiate poultry farming, with an additional income of Rs 12,500-17,000 per year.

The multipurpose tree plantation was initiated in cultivable wasteland belonging to five families. The area was planted with tejpatta (Cinnamomum tamala), citrus species and multipurpose fodder species such as bhimal 
Table 6. Adopted technologies and income generated by beneficiaries in the target area

\begin{tabular}{|c|c|c|c|c|c|c|}
\hline Interventions & $\begin{array}{l}\text { Size of land } \\
\text { treated/covered/ } \\
\text { material used }\end{array}$ & $\begin{array}{l}\text { Adoption } \\
\text { (no. of } \\
\text { villages) }\end{array}$ & $\begin{array}{c}\text { No. of } \\
\text { beneficiaries }\end{array}$ & $\begin{array}{c}\text { Mean } \\
\text { income/family/ } \\
\text { year (before } \\
\text { implementation of } \\
\text { the programme) }\end{array}$ & $\begin{array}{l}\text { Mean income/ } \\
\text { family/year (after } \\
\text { implementation of } \\
\text { the programme) }\end{array}$ & $\begin{array}{l}\text { Enhancement } \\
\text { in income }(\%)\end{array}$ \\
\hline \multicolumn{7}{|l|}{ On-farm technologies } \\
\hline Polyhouse & $9 \times 3 \times 2.5 \mathrm{~m}$ & 6 & 21 & $98,000.8$ & $121,232.1$ & 23.7 \\
\hline $\begin{array}{l}\text { Cash-crop cultivation on } \\
\text { abandoned land }\end{array}$ & 2.5 ha & 1 & 21 & $51,428.2$ & $62,142.32$ & 20.8 \\
\hline $\begin{array}{l}\text { Cash-crop cultivation on } \\
\text { low productive } \\
\text { agriculture land }\end{array}$ & $12.71 \mathrm{ha}$ & 8 & 305 & $55,000.4$ & $75,232.75$ & 36.8 \\
\hline $\begin{array}{l}\text { Vegetable cultivation in } \\
\text { kitchen gardens }\end{array}$ & $4.3 \mathrm{ha}$ & 8 & 46 & $9,500.6$ & $11,115.0$ & 17.0 \\
\hline Integrated fish farming & $20 \mathrm{~m} \times 10 \mathrm{~m}$ & 2 & 2 & $150,000.6$ & $197,530.3$ & 31.7 \\
\hline Poultry farming & $5 \mathrm{~m} \times 4 \mathrm{~m} \times 3 \mathrm{~m}$ & 7 & 15 & $42,000.4$ & $58,600.81$ & 39.5 \\
\hline \multicolumn{7}{|l|}{ Off-farm technologies } \\
\hline Bio-briquetting & $\begin{array}{c}3750 \mathrm{~kg} \text { dry pine } \\
\text { needle }\end{array}$ & 4 & 34 & $12,199.9$ & $14,228.93$ & 16.6 \\
\hline $\begin{array}{l}\text { Handmade paper at pine } \\
\text { processing unit }\end{array}$ & $\begin{array}{l}5000 \mathrm{~kg} \text { dry pine } \\
\text { needle }\end{array}$ & 2 & 10 & $34,800.32$ & $41,300.00$ & 18.68 \\
\hline
\end{tabular}

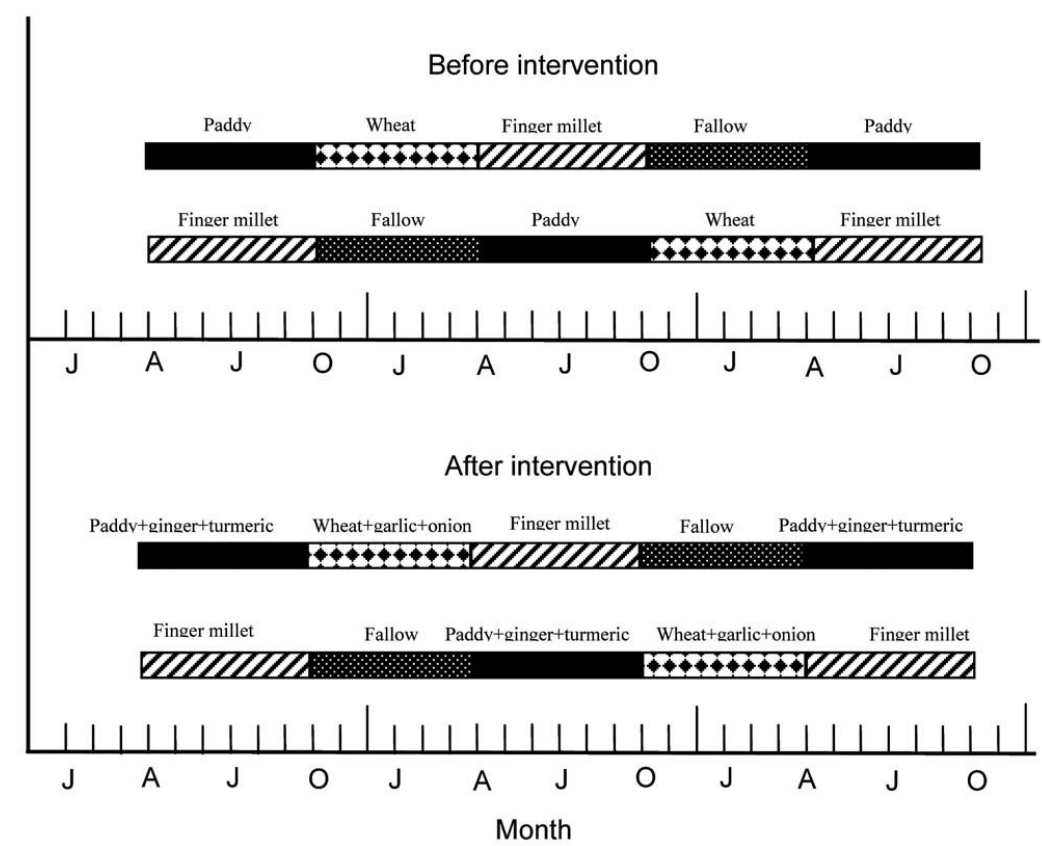

Figure 4. Comparison of cropping pattern before and after implementation of the programme (symbols in $x$-axis comprised months starting from January and continued in sequence for next three years).

(Grewia optiva), falyat (Quercus glauca), Quiral (Bauhinia variegata), etc. based on community and market demands. After two years of plantation, $90 \%$ of the plants have survived.

Promotion of bio-briquettes made up of chir-pine needles as well as making decorative items from chirpine cones and leaves was also undertaken, which benefitted 90 households. The bio-briquetting moulds (frames) were distributed in all target villages. Most of the households have adopted bio-briquettes for cooking, heating and other household works. A low-cost stove (kiln) was also designed for using bio-briquettes efficiently and distributed to 32 poor households. Some villagers have started selling bio-briquettes and earned up to Rs 35,000 in a year. Bio-briquettes have also reduced the drudgery of women involved in collecting fuelwood. With the success of this project, the District Administration has also initiated a project on bio-briquettes. After 
Table 7. Details of self-help groups (SHGs) formulated in the study area

\begin{tabular}{|c|c|c|c|}
\hline Self-help group & Village & Total members & Activities performed \\
\hline Sadhana Utpadan Samuh & Darimkhola & 8 & $\begin{array}{l}\text { Cash-crop cultivation } \\
\text { Bio-briquetting of chir-pine needles }\end{array}$ \\
\hline Sahara Utpadan Samuh & Darimkhola & 9 & $\begin{array}{l}\text { Goat farming } \\
\text { Bio-briquetting of chir-pine needles }\end{array}$ \\
\hline Prayas Utpadan Samuh & Darimkhola & 11 & Dairy farming \\
\hline Vikas Utpadan Samuh & Sakar & 11 & $\begin{array}{l}\text { High-value cash-crop cultivation } \\
\text { Organic vegetable cultivation }\end{array}$ \\
\hline Zyan Utpadan Samuh & Gwalakot & 9 & $\begin{array}{l}\text { Collection and supply of raw materials (chir-pine needles) to } \\
\text { pine processing unit } \\
\text { Making decorative items from pine needles and cone } \\
\text { Bio-briquetting of chir-pine needles }\end{array}$ \\
\hline Parayaran Sarankchan Samiti & Sakniyaktot and Bhelgarh & 8 & Bio-briquetting of chir-pine needles \\
\hline Murgi Utpadak Samuh & Tiloura & 15 & Poultry farming \\
\hline Ekel Mahila Samuh & Jyula & 5 & $\begin{array}{l}\text { Cash-crop production } \\
\text { Poultry farming }\end{array}$ \\
\hline
\end{tabular}

Table 8. Linkages with various line departments and support extended to the target villages

\begin{tabular}{ll}
\hline Line department & \multicolumn{1}{c}{ Type of linkage } \\
\hline Horticulture Department & Distribution of $100 \mathrm{~m}^{2}$ polyhouses \\
Livestock Department & Financial assistance for poultry and dairy \\
Agriculture Department & Seeds of high-yielding variety of cash crops \\
& Construction of retaining walls to check soil erosion \\
& Financial assistance for vermicompositing \\
Rural Development (through MGNREGA) & Financial assistance for poultry and goat farming \\
& Water harvesting ponds (three) \\
\hline
\end{tabular}

successful training, 32 women have started making decorative items from chir-pine cone that may provide good income in the future.

A Chir-pine Processing Unit was established at RTC, where handmade paper and other items (file cover, folder, carry bags, etc.) are being made from chir-pine needles. The village women have been collecting chir-pine leaves from the forest floor during summer months and selling them to the Unit, thus earning income. Besides, the women SHGs formulated in different villages have also been trained in various other activities to earn a livelihood (Table 7). SHGs are linked with local markets for selling their products. Since the State Government runs various developmental programmes for the benefit of the community, the Departments of Agriculture, Horticulture, Livestock, Forest and District Administration were approached to undertake their departmental activities in the target villages. Interestingly, such linkage has benefitted over 300 farm families under various on-going schemes (Table 8).

\section{Conclusion}

Rural livelihood in the Himalayan region has been intensely dependent on natural resources. A cluster of eight villages was targeted for undertaking this study that corresponds to a typical rural set-up in the Central Himalayan region. Agriculture has been the mainstay of these people with high dependence on natural resources. The area suffered economic exclusion that impedes development in the region. The selected villages have been characterized with small land-holding sizes, fragmented and rainfed agricultural land, low productivity of crop fields, lack of market linkages and alternative means of income, and poor socio-economic status of the communities. People have limited capacity to cope with the challenges of land degradation, soil fertility loss, low productions, land abandonment and adverse impact of climate change. There has been significant out-migration in search of employment. The present study describes the outcomes of a project that was implemented in the target area. The approach comprised of efficient management of natural resources, devising appropriate land-use practices, maintaining sustained agricultural yield using simple, lowcost, eco-friendly and replicable technology packages, capacity-building of farmers, strengthening of village institutions and community governance, and mainstreaming Government-run schemes in target villages. The problem identification and implementation of technology packages through participatory process have been successful in improving resource status and livelihood. The study found 
that farmers prioritized nine technology packages for adoption that diversified agriculture in waste, abandoned and low-yield cultivable lands, thus making them more profitable. Capacity-building of farmers in low-cost technologies helped them to adapt to change as well as organized themselves into SHGs for better advocacy. Cultivation of cash crops resulted in additional income to the farmers. They adopted cash-crop cultivation (onion, ginger, garlic and turmeric) in the place of traditional crops, as it was more profitable. Even the less-productive land provided better returns by cultivating cash crops. Protected cultivation successfully demonstrated growing vegetables round the years. Converting chir-pine needles in bio-briquettes provided an additional source of income to the villagers. Also, the use of chir-pine needles to make various economic by-products has not only provided an additional source of livelihood, but also helped in controlling the forest fires. A Chir-pine Processing Unit was established under the project that has started producing paper sheets of 200-500 GSM from dry chirpine needles that are made into file covers, folders, bags, etc. It shows the potential of creating job opportunities for local people. Linkages were established with various line departments to access the benefits of Governmentrun developmental schemes in target villages that benefitted 300 families in the target area.

Sustainable development approach for the Indian Himalayan Region (IHR) needs equal emphasis on economic and ecological concerns ${ }^{11}$. There have been several attempts to implement sustainable natural resource management approach for the IHR with varied levels of success $^{7,9,10}$. It is argued that in the IHR a generalized, uniform, sustainable development model for managing and planning of natural resources can only be of limited use because of the complexity in topography, climate and elevation in the region ${ }^{7}$. Therefore location-/area-specific land-use models based on ecological, social and cultural considerations are the most desired ${ }^{12}$. Unfortunately crop diversity in traditional farming, which was an important aspect of avoiding crop failure, is declining alarmingly thus threatening sustainable livelihood in the Central Himalaya $^{8,9}$. Often the communities value immediate economic benefits rather than the long-term benefits of tree and multipurpose tree planting ${ }^{13}$. The findings reveal that IHR is facing anthropogenic pressure that causes overall environmental degradation. Traditional and ethnic communities have strong village-level institutions to manage natural resources with due incentive to all sections of the society ${ }^{14}$. However, where such provisions are not available, empowering rural women and weaker sections is strongly desired for sustainable livelihoods through natural resource management ${ }^{2}$. In recent years, many new sectors have emerged that have shown high potential for rural development, such as horticulture, livestock, medicinal plants, floriculture, ecotourism, etc. Building farmers' skills, village-level institutions and governance, community empowerment can lead to mainstream such interventions in rural areas. Considering that agriculture and forest are the two important aspects of rural livelihood to supply food, fuel, fodder and water security, adoption of better agricultural practices and better crop varieties, and ecological restoration of village community lands and degraded land in participatory mode for biodiversity conservation and socio-economic development is highly desirable in the IHR ${ }^{15}$. Besides, implementation of appropriate schemes and policies is urgently required to provide solutions and opportunities to overcome threats and to halt the continuing erosion of genetic resources ${ }^{10}$. Bio-briquetting from the biomass of chir-pine needles and other forest resources helped improvize energy use and community gains from this least used material. In Nepal, bio-briquettes made from agricultural waste have brought novel fuel prospects for the community ${ }^{16}$. Products such as paper, file covers, bags and other decorative items from chir-pine have also brought new income avenues for the community. Chir-pine needles can be a sustainable source of raw material for paper-making and energy in view of their abundance in the forest areas ${ }^{17,18}$. Awareness was created to popularize the findings of the research to other areas. Media coverage has generated the public interest in the project. The District Administration and line departments are keen about the project and extending all possible help for its smooth implementation in block level or district level.

We strongly realize that the livelihood and natural resource management-related initiatives and interventions through this project are still midway and need continuous support for the next few years. Therefore, it is recommended that collective action for efficient management of natural resources, promoting livelihood activities and community empowerment should be continued for improving economy and ecology of the people in the region. The study has yielded significant learnings to organize communities, prioritize activities, need of training and capacity-building of farmers, selection of appropriate models for demonstration, providing technical back-up when necessary, community-led monitoring of various interventions, maintaining environmental health and mainstreaming/gelling with on-going Government schemes. It is expected that the process will be smoothened further as well as upscaled in near future. It is strongly desired that similar efforts continued so that people are engaged in productive action to earn livelihoods through natural resource management, thus contributing substantially to national-building.

1. Sundriyal, R. C., Rai, S. C., Sharma, E. and Rai, Y. K., Hill agroforestry systems in south Sikkim, India. Agrofor. Syst., 1994, 26(3), 215-235.

2. Sundriyal, R. C., Negi, G. C. S., Maikhuri, R. K., Rawat, D. S., Rawal, R. S. and Dhyani, P. P., Family and smallholder farming in Himalayan communities. In Deep Roots, FAO, Rome, Italy and Tudor Rose, UK, 2014, pp. 105-108; 253. 
3. Singh, S. P., Balancing the approaches of environmental conservation by considering ecosystem services as well as biodiversity. Curr. Sci., 2002, 82(11), 1331-1335.

4. Maikhuri, R. K., Sundriyal, R. C., Negi, G. C. S. and Dhyani, P. P., Smallholders and family farming in the Himalayan region of India: policy considerations. Policy Focus, 2015, 34, 21-23.

5. Negi, G. C. S., Dhyani, P. P. and Sundriyal, R. C., Wasteland rehabilitation for sustainable agriculture in the Indian Himalayan region. Living Land, UNCCD, Germany and Tudor Rose, UK, 2015, pp. 159-162.

6. Anon., Interim report on the status of migration in Gram Panchayats of Uttarakhand. Rural Development and Migration Commission, Government of Uttarakhand, Pauri Garhwal, 2018.

7. Rawat, D. S., Farooquee, N. A. and Joshi, R., Toward sustainable land-use in the hills of Central Himalaya, India. Int. J. Sustain. Dev. World Ecol., 1996, 3(2), 57-65.

8. Rao, K. S. et al., Indigenous ecological knowledge, biodiversity and sustainable development in the central Himalayas. Trop. Ecol., 2003, 44(1), 93-111.

9. Maikhuri, R. K., Semwal, R. L., Rao, K. S. and Saxena, K. G., Agro forestry for rehabilitation of degraded community lands: a case study in Garhwal Himalaya. Int. Tree Crops J., 1996, 9, 89-99.

10. Negi, V. S., Maikhuri, R. K., Chandra, A., Mathela, A. and Dhyani, P. P., Assessing sustainability of farming systems in mountain agro-ecosystems of Western Himalaya, India. Agroecol. Sustain. Food Syst., 2018, 42(7), 751-776.

11. Singh, J. S., Sustainable development of the Indian Himalayan region, linking ecological and economic concerns. Curr. Sci., 2006, 90(6), 784-788.

12. Shah, S. L., Planning and Management of Natural and Human Resources in the Mountains, Yatan Publications, New Delhi, 1986.
13. Saxena, K. G., Rao, K. S., Sen, K. K., Maikhuri, R. K. and Semwal, R. L., Integrated natural resources management: approaches and lessons from the Himalaya. Conserv. Ecol., 2001, 5(2), 1-14.

14. Sundriyal, R. C. and Dollo, M., Integrated agriculture and allied natural resource management in northeast mountains: transformations and assets building. Agroecol. Sustain. Food Syst., 2013, 37(6), 700-726.

15. Rawat, L. S., Maikhuri, R. K., Dhyani, D., Bahuguna, M. B. and Pharswan, D. S., Ecological restoration of village common degraded land through participatory approach for biodiversity conservation and socio-economic development in Indian Himalayan Region. Acta Ecol. Sin., 2017, 37, 240-252.

16. Singh, R. M., Bio-briquetting in Nepal-scope and potential: a review. Kathmandu Univ. J. Sci. Eng. Technol., 2013, 9(2), 104120.

17. Lal, T. S., Sharma, A. and Bisht, V., Pine needle - an evaluation of pulp and paper making potential. J. For. Prod. Ind., 2013, 2, $42-47$.

18. Bisht, S. A., Singh, S. and Kumar, R. S., Pine needles a source of energy for Himalayan region. Int. J. Sci. Technol. Res., 2014, 3(12), 161-164.

ACKNOWLEDGEMENTS. We thank the Director, G. B. Pant National Institute of Himalayan Environment and Sustainable Development, Almora, for providing the necessary facilities. The support of the target community from study area is acknowledged. This work has been supported by the Ministry of Environment and Forest, Government of India through the National Mission on Himalayan Studies programme.

doi: $10.18520 / \mathrm{cs} / \mathrm{v} 120 / \mathrm{i} 5 / 825-834$ 